\title{
Correction: MMP9/RAGE pathway overactivation mediates redox dysregulation and neuroinflammation, leading to inhibitory/ excitatory imbalance: a reverse translation study in schizophrenia patients
}

\author{
Daniella Dwir - Basilio Giangreco - Lijing Xin - Liliane Tenenbaum (1) - Jan-Harry Cabungcal • Pascal Steullet • \\ Audrey Goupil - Martine Cleusix - Raoul Jenni - Abdelwahed Chtarto - Philipp S. Baumann - Paul Klauser - \\ Philippe Conus $\cdot$ Rabindra Tirouvanziam $\cdot$ Michel Cuenod $\cdot$ Kim Q. Do
}

(c) The Author(s) 2020. This article is published with open access

\section{Correction to: Molecular Psychiatry \\ https://doi.org/10.1038/s41380-019-0393-5 \\ published online 25 March 2019}

In the original version of this article 'Abdelwahed Chtarto' was omitted from the author list. This author has now been added to the author list in 10th position.

Additionally, the following acknowledgement was accidentally omitted from the original article: 'We are grateful to Catherine Melas, from the ULB, and Laetitia Thieren, from the CHUV, for their valuable help on producing the viruses used in this study'.

This has been corrected in both the PDF and HTML versions of this article.
Open Access This article is licensed under a Creative Commons Attribution 4.0 International License, which permits use, sharing, adaptation, distribution and reproduction in any medium or format, as long as you give appropriate credit to the original author(s) and the source, provide a link to the Creative Commons license, and indicate if changes were made. The images or other third party material in this article are included in the article's Creative Commons license, unless indicated otherwise in a credit line to the material. If material is not included in the article's Creative Commons license and your intended use is not permitted by statutory regulation or exceeds the permitted use, you will need to obtain permission directly from the copyright holder. To view a copy of this license, visit http://creativecommons. org/licenses/by/4.0/. 